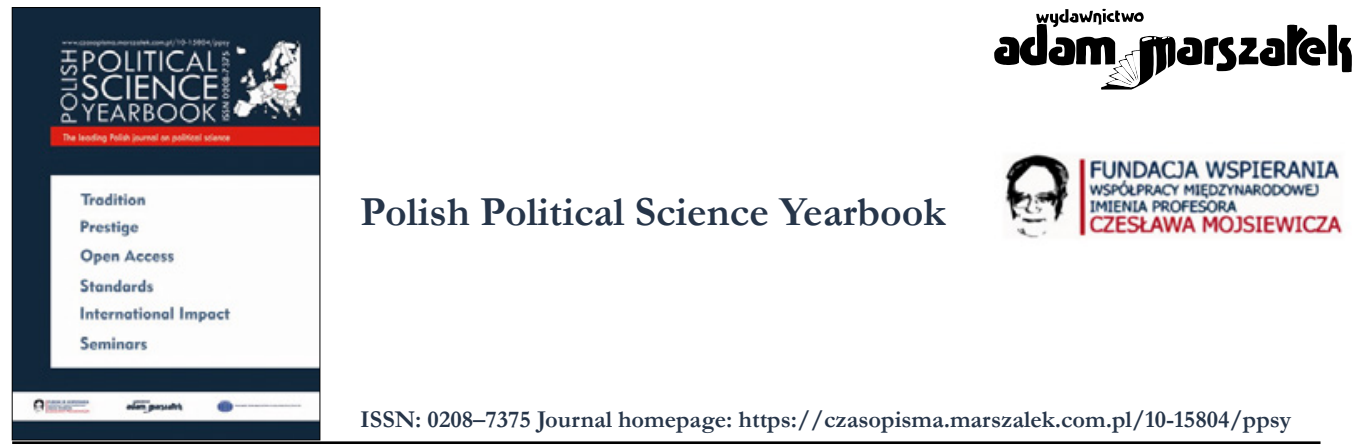

\title{
The United States in India's Strategy in the Indo-Pacific Region Since 2014
}

\section{Jakub Zajączkowski}

ORCID: 0000-0002-1459-3850

To cite this article please include the following information:

- Journal title: Polish Political Science Yearbook

- Volume number: 50

- Year of publication: 2021

- Published ahead-of-print

Example styles:

[APA Style]: Zajączkowski, J. (2021). The United States in India's Strategy in the IndoPacific Region Since 2014. Polish Political Science Yearbook, 50(4), pages. https://doi. org/10.15804/ppsy202158

[Chicago Style]: Jakub Zajączkowski, “The United States in India's Strategy in the IndoPacific Region Since 2014” Polish Political Science Yearbook 50, no. [4] (2021).

To link to this article: https://doi.org/10.15804/ppsy202158

Published ahead-of-print

\begin{tabular}{l} 
Published online: 17 December 2021 \\
\hline Printed issue: 2021 \\
Submit your article to PPSY
\end{tabular}




\title{
Jakub Zajączkowski
}

University of Warsaw (Poland)

ORCID: 0000-0002-1459-3850

e-mail: j.zajaczkowski@uw.edu.pl

\section{The United States in India's Strategy in the Indo-Pacific Region Since 2014 ${ }^{1}$}

\begin{abstract}
This article analyzes the main assumptions of India's strategy in the Indo-Pacific region and the role of the US in that strategy. The time frame of the article has been determined by the assumption of power in India in 2014 by the Indian People's Party (Bharatiya Janata Party, BJP), led by Prime Minister Narendra Modi, as well as the opening of a new stage of the US-led Indo-Pacific rebalancing strategy, which followed China's initiation in 2013 of its Belt and Road Initiative (previously known as the One Belt One Road project). The article seeks to answer the following main research question: What role has India attributed to the United States in its Indo-Pacific strategy since 2014? It hypothesizes that the United States has assumed an increasingly significant role in India's regional strategy over the past seven years, but not to the extent of a formal alliance, only approaching at best the status of a strategic partnership. The theoretical framework used to analyze the case study of the US role in India's regional strategy is based on institutional balancing and the assumptions of neoclassical realism. The choice of such research tools was determined by their explanatory value. Moreover, both models complement each other. The first part of the article presents the general assumption of the analysis and the theoretical framework. The second discusses the evolution of India's approach to the US from 2014 to 2021, indicating the reasons for its change and reconstructing the role of the US in Indian regional strategy, especially after 2020 . The third part draws on the theoretical framework adopted in the article, i.e., the assumptions of institutional balancing and neoclassical realism, to offer conclusions that answer the main research questions.
\end{abstract}

Keywords: India, strategy, the United States, the Indo-Pacific region

${ }^{1}$ I would like to thank Professors: Edward Haliżak, Roberto Rabel, and Dorota Heidrich for their valuable comments. 


\section{Assumptions of the Analysis}

The main research problem is the importance of the US in India's strategy in the Indo-Pacific region. The dependent variable, which will be analyzed using qualitative methods (discourse analysis), is India's strategy towards the US and its importance in India's regional policy after 2014. Independent variables are: the US regional strategy in the Indo-Pacific after 2014; China's regional strategy after 2014 and intra-regional relations, and primarily US-China relations; internal conditions in India, mainly the strategic culture and decision-making process in its foreign policy.

The choice of the research problem was mainly based on four premises:

a) the tightening of political relations between India and the US, which manifested itself after 2014 in the process of creating a more visible institutional framework for bilateral cooperation and creating a coalition of states with the US in a tripartite (e.g., US-Japan-India) or the Quadrilateral Security Dialogue (QUAD) format, i.e., India, the US, Australia, and Japan;

b) the dilemma faced by India in the context of increasing China-US rivalry and the resulting implications for international relations in the Indo-Pacific region, creating a possible bipolar structure in the region;

c) the American factor has started to play a key role in the strategic debate in India and the discourse on India's new international identity in the region;

d) India has become, especially since 2013 and the implementation by China of its Belt and Road Initiative (BRI), a key country in the context of the United States' rebalancing strategy. The US realized that without India's involvement in the region, the Indo-Pacific concept promoted by Washington would not be fully effective.

A new stage in relations between India and the US, visible in terms of greater cooperation in the political dimension, resulted in an increased interest in this issue by researchers from India, the US, and other countries. Most of the publications, however, focus on the analysis of the role of the US in India's strategy in the context of the newly emerging Indo-Pacific region and analyze US-India relations through the prism of the Chinese factor. This tendency is evidenced in numerous publications (Brewster, 2014; Gopal \& Ahlawat, 2016; Chacko, 2016; Chandra \& Ghoshal, 2018). Most of the authors focus primarily on the impact of the American factor on the role and position of India in the region and on both material and non-material aspects of India's regional strategy. Moreover, relations between India and the US have been perceived in the context of the QUAD, which dominated the debate especially after 2017, i.e., after India, the US, Japan, and Australia returned to this idea, and the first meeting of these countries in the above format was held in 2017 (Marszałek-Kawa \& Bodio, 2016). Two groups of researchers can therefore be identified.

The first one has mainly focused, inter alia, on the different definitions of the Indo-Pacific region by the QUAD countries, including the US and India, and to significant differences of interests in terms of the approach to relations with China or other geographical priorities 
in such an extensive region (for example, India focuses primarily on the north-eastern and north-western part of the Indian Ocean, and the US on the Pacific) (Roy-Chaudhury \& de Estrada, 2018,pp. 181-194). Moreover, the structural differences and different geopolitical interests of India and the US in the western part of the Indian Ocean have been emphasized, as well as the incompatibility and interoperability of American and Indian forces (Pant \& Rej, 2018, pp. 47-61). It was pointed out that India is, in fact, the weakest link in the QUAD structure, as it is not connected with the US by alliance agreements, unlike Australia or Japan. At the same time, it was noted out that India was still not the main strategic partner for the United States in the region (Lalwani \& Byrne, 2019, pp. 41-64; White, 2019, pp. 407-436).

The second group of researchers, especially exponents of neorealism, emphasized a new stage in relations between the US and India. They have pointed out that India would be a key country in the new American strategy of balancing China, as well as that India was departing from the assumptions of the policy of non-alignment, as evidenced by India-US relations. Some have argued that, given the growing power of the PRC and its assertive policy, India changed its strategy toward Beijing from soft power to hard power policies (Pant, 2019, pp. 386-404; Scott, 2021; Paul, 2019, pp. 221-242). India's closer relations with the US were explained mainly in the context of expanding India's sphere of influence in the Indo-Pacific region. Some researchers perceived it in the context of India's new international identity as an attempt to define its role as an Indo-Pacific power (Chacko, 2014, pp. 433-452; Singh, 2014,pp. 187-211).

Most publications, however, to a small extent, refer to the main theoretical trends in explaining India’s new policy on the Asian continent (Zajączkowski, 2015, pp. 37-70; Paul \& Underwood, 2019, pp. 348-367). If some researchers try to refer to theoretical models when explaining the role of the US in India's strategy, they do so in a way that seems too simplified, focusing mainly on neorealist assumptions. Taking into account the main dependent variable, i.e., the change in India's approach to cooperation with the US, it must be clearly stated that there is no theoretical explanation of the manifestations of this modification, which would take into account the complexity of the selected research problem, primarily the specificity of both intra-regional conditions, as well as tradition, culture, and the strategic debate in India.

In order to address the research problem, an analytical approach will be used, consisting of the instrumental and heuristic use of a given theory and theoretical model. In such a situation, as a simplified reflection of reality, the theory directs attention to factors (variables) that it considers key to explaining a given phenomenon (Jackson, 2011). This process is defined as operationalizing a theory or a given theoretical model. It includes the following activities: presenting the assumptions of the institutional balancing model and neoclassical realism, including the indication of key variables in these models, which allow for the interpretation and explanation of the empirical material.

The following arguments determine the analytical usefulness of the combined application of institutional balancing and neoclassical realism: 
a) The approaches are complementary. The first emphasizes the importance of external balancing to a greater extent; the second, without questioning the importance of systemic factors and the international structure, indicates the importance of the specificity of each country, intangible factors, and the decision-making process.

b) Taking these two models together in explaining the role of the US in India's strategy will allow understanding of the complexity and specificity of India's regional strategy.

The assumptions of the institutional balancing model are presented in an article by Kai He entitled „Institutional Balancing and International Balancing Theory: Economic Interdependence and Balance of Power Strategies in Southeast Asia" in the European Journal of International Relations (He, 2008, pp. 489-518).

Kai He points to such main assumptions of this model as:

a) paying attention to the importance of two aspects of balancing in explaining the strategies of states, which are: external balancing (i.e., concluding agreements, building institutions, forms of consultation with other states) and internal balancing (i.e., expanding one's own potential);

b) highlighting the fact that external balancing can significantly complement and strengthen the so-called internal aspect of balancing;

c) the significance of the interplay between the distribution of power in the system and economic interdependence - which determines states' behavior (a case study of India, Australia, and China economic cooperation);

d) that the core causal mechanism in the model constitutes the rationality criterion in the form of cost-benefit calculations (and expectations); the stronger the perceptions of interdependence, the more risky and costly is military balancing;

e) the complexity of relations at the regional and global level and the interdependence between states (He, 2008, pp. 489-518).

The usefulness of the proposed model in the study of intra-regional relations in the region, especially the Indo-Pacific, is determined by the fact that it emphasizes issues of complexity and stresses both elements of cooperation and competition. Moreover, this model is primarily used to explain countries' foreign policies.

These theses also coincide with the main assumptions of neoclassical realism, which began to develop in the 1990s. This approach explains the differences in states' foreign policy in similar conditions. Although the state's actions in foreign policy constitute a reaction, a response to external challenges, unlike the institutional balancing model, it primarily emphasizes internal factors. While the representatives of institutional balancing consider the structure of the international system as an independent variable in the context of external, systemic factors, researchers associated with neoclassical realism consider them through the prism of internal-state factors. They believe that the manner of implementing foreign policy and its operationalization depend on such variables as the internal structure of the state, relations at the state-society level, political processes within the state, and strategic culture. Internal pos- 
sibilities and limitations should be treated as an intervening variable that affects the dependent variable, i.e., the state's foreign policy and the independent variable - power distribution in the international system and the international structure (Kozub-Karkut, 2020).

Among the internal factors which affect the shaping of foreign policy and its operationalization, representatives of neoclassical realism also highlight such conditions as the level of economic development of the state, its institutional, legal, and systemic mechanisms, and the political system or role of leaders. In addition, representatives of European neoclassical realism emphasize the importance of non-material elements, such as cultural and civilization factors or identity.

While in the case of emphasizing the importance of individual elements of balancing, the two approaches used in the article differ, the convergent factor of neoclassical realism and institutional balancing constitutes the inclusion of rationality criteria based on the cost-benefit model in the study of the state's foreign policy. Representatives of neoclassical realism assume that in the event of a growing sense of threat, the state is inclined to ally with a geopolitically less threatening rival. In this context, it is also worth noting that, as Jacek Czaputowicz points out, countries in a situation of a threat from the main enemy in relations with their allies and strategic partners, with whom they also have different interests, visions and even compete - tend to emphasize and overestimate the role and influence of concessions of marginal importance on the part of the partner or to ignore or disregard the partner's inappropriate behavior (Czaputowicz, 2014, pp. 25-42). Many internal variables will simultaneously condition the state's behavior in this context.

Advocates of institutional balancing point to the limitations of both neorealism, which primarily emphasizes the rivalry and competitive strategy of powers, and neoliberalism, which mainly emphasizes the aspects of cooperation between states. Moreover, the model of institutional balancing is not a theory intended to explain the reasons for the cooperation of states within institutions and the formation of institutions. The dependent variable constitutes here the behavior of states in international relations - foreign policy, instruments used during its operationalization - and not the political result or effect in the form of peace or war. Institutional balancing equally focuses on explaining the essence of such processes as negotiations, bargaining between states, pursuing a balancing policy, concluding agreements and treaties. Kai He defines institutional balancing as a new type of balancing, the so-called soft balancing behavior. Soft balancing, however, is not the same as institutional balancing. The former can be implemented through various instruments, such as ad hoc alliances, coalitions, or multilateral institutions. The key point is that this category focuses to a greater extent on balancing or its instruments, and to a lesser extent on the premises, motives for making decisions by states in foreign policy. In this context, the explanatory role is played by the assumptions of institutional balancing, which presume that the main research goal is to identify and define the motives of states' actions in foreign policy (He, 2008, p. 493).

At the same time, the author of this article modifies the assumptions of the model presented by $\mathrm{He}$, as he defines institutions much more widely than $\mathrm{He}$, who focuses on 
multilateral institutions. The author, taking into account, first of all, the specificity of the regional security system in the Indo-Pacific region, which is reflected in the number and diversity of undertakings in the political and economic sphere, as well as the behaviors typical of local societies and states, such as informality, pragmatism, consensus, and evolution, understands institutions broadly. It means that he recognizes as institutions such forms of initiatives as bilateral security and economic institutions, temporary and ad hoc institutions, loose coalitions of states, regional fora and institutions, tripartite agreements, and other multilateral cooperation formats (Haliżak, 1999, pp. 362-364; Ball, 1993, pp. 44-74; Marszałek-Kawa \& Kinelski, 2019).

Institutional balancing may be, referring again to He's terminology, either inclusive or exclusive. The first of them should be understood as the creation by states of norms, principles, and rule-building in order to limit or enforce specified behaviors or actions in other states within a given institution or area; the second means the political and economic consolidation of states in order to counteract an external threat (He, 2008, p. 493).

For exponents of institutional balancing and neoclassical realism, the key issue in defining the actions of states in the field of foreign policy is the category of the perception of the distribution of power in the international system. According to the researchers of these two approaches, it is not the strength or distribution of power itself that is the key to making certain decisions by states, but the perception of this distribution by decision-makers and politicians. Their perception and assessment of the power distribution influence the decisions made by states (Wohlforth, 1994, pp. 91-129; Rose, 1998, pp. 144-172).

With these methodological and theoretical assumptions, the article seeks to answer the following research question:

What role has India attributed to the United States in its Indo-Pacific strategy since 2014?

These are important questions both from the cognitive and practical point of view, as they allow for the assessment of the assumptions of neoclassical realism and institutional balancing as a research tool.

\section{Evolution of India's Position Toward the US and Manifestations of Their Political Cooperation}

The 2014 Indian elections and the victory of the Indian People's Party, and the new US strategy in the Asia-Pacific from the same time had a significant impact on a new stage in India's relations with the US.

Even though from the beginning of the $21^{\text {st }}$ century New Delhi and Washington had tightened their relations, were creating a legal and institutional framework and there was an increase in economic exchange, both the Indian and the American sides were still cautious 
about creating allied relations in the political dimension. The agreements in the political field concluded in 2004 and 2005 were not implemented, and de facto remained only in the declarative sphere (Zajączkowski, 2011,pp. 487-508).

As noted by H.V. Pant, the United Progressive Alliance coalition led by the Indian National Congress, which was ruling since 2004, „persistently declined to consummate the 2005 defense agreement with the US. Three crucial elements of the Next Step in Strategic Partnership (NSSP) - Logistics Sharing Agreements (LSA), Communication Interoperability and Security Memorandum of Agreement (CISMOA), and the Basic Exchange and Cooperation Agreement for Geo-spatial Cooperation (BECA) - were given short shrift by the UPA government" (Pant, 2019, p. 394). In addition, after the global financial crisis of 2008/2009, following the border tensions with China in 2010, a sense of strategic uncertainty increased in India's ruling camp. Anti-American sentiments and nostalgia for the policy of non-alignment emerged among some of the UPA's party leaders (Pant, 2019, p. 395). At the same time, the position of Prime Minister Manmohan Singh, due to the economic slowdown, corruption scandals, and coalition instability, was much weaker in his second term (2009-2014) than in the first term (2004-2009). Hence, he could not operationalize initiatives to strengthen political relations with the US. In this respect, he encountered resistance even from some of his ministers, e.g., Defense Minister A.K.Antony (Baru, 2014).

At the same time, despite the initiation of the pivot and rebalancing policy by the US in the Asia-Pacific region, Washington did not treat India as its main partner in the region. In the US National Bureau of Asian Research report from 2013, India was defined as a global swing state that defines its priorities, considering changes in the existing international system (India as Global Swing State, 2013).

After 2014, internal conditions in India and the US changed significantly. Two variables should be considered when analyzing the American factor in Indiass strategy after 2014.

First, the election of the prime minister as N. Modi, opened a new stage in India's strategy towards the Indo-Pacific region. It was demonstrated both by the new policy in the immediate vicinity of South Asia (Pattanaik, 2016, pp. 126-142) and in Southeast Asia, East Asia (Garge, 2017, pp. 150-167), and the Indian Ocean. The new policy was characterized by assertiveness and an attempt to holistically treat these subregions as part of a single geopolitical and geo-economic whole, which is the Indo-Pacific. Cultural and civilizational ties also featured in this respect. It was accompanied by a fundamental ideological and identity shift in India's foreign policy, characterized by: assertiveness, activity, commitment, and emphasis of the ideological foundations of the new strategy (Hall, 2016, pp. 271-286; Tandon, 2016, pp. 349-356), with issues relating to national security assuming greater prominence than before. Moreover, the new government departed from the passivity often associated with the ingrained ideas of non-involvement in favor of active involvement in creating the regional order. „The BJP government has led to a shift in Indian strategy from hedging to an active partnership of managing power transition in Indo-Pacific" (Pant, 2019, 
p. 398). India began to define itself as an Indo-Pacific power. Thus, it wanted to go beyond being perceived only in categories of South Asian power. Moreover, as pointed out by C. Raja Mohan, India realized that implementing superpower aspirations in the new conditions will only be possible thanks to intensifying cooperation with the current superpowers, including the US (Raja Mohan, 2006). The new government believed that in the face of intra-regional dynamics characterized by strategic uncertainty, countries such as India and Japan should take greater responsibility for stability in the region.

Secondly, after 2013, the United States began to treat India as an important actor on the Asian continent, rhetorically and conceptually. It was reflected, inter alia, in statements made by US politicians and strategists (Clinton, 2011) and in documents adopted by Barack Obama's administration (Sustaining U.S. Global Leadership, 2012). India's role has come to be perceived in a broader context. The United States increasingly emphasized the interdependence between the Indian Ocean region and the Asia-Pacific region. In the statements of the American administration, the term Indo-Pacific appeared (Willard, 2012). The importance of this area was emphasized, among others, by Hilary Clinton in her article in Foreign Policy (Clinton, 2011). Department of Defense guidelines from 2012, entitled Sustaining U.S. Global Leadership: Priorities for $21^{\text {st }}$ Century Defense, indicate that the US security interests are interrelated in the area between the Western Pacific and the Indian Ocean (Sustaining U.S. Global Leadership, 2012, p. 2). India's role in this regard was also highlighted in the Quadrennial Defense Review 2014, published by the US Department of Defense (Quadrennial Defense Review 2014, 2014). The US' new perception of the region was confirmed by using the term Indo-Asia-Pacific in the maritime strategy adopted in 2015, instead of the traditional term Asia-Pacific, and in 2017 the term Indo-Pacific was officially used for the first time in the National Security Strategy.

The change in the strategies of both India and the United States was a response to the increasingly assertive policy of China. One of the reasons for the beginning of a new stage in US-India relations was the attempt to oppose the Chinese BRI project (Pan, 2014, pp. 453-469) and the willingness of both India and the US to maintain a liberal order in the Indo-Pacific region (Oertel, Small, \& Studdart, 2018). Despite these common challenges, the dynamics of Indian-American relations fluctuated as a function of not only external but also internal conditions. It should also be emphasized that although India was in favor of maintaining the current regional and global order, from which it benefits, it perceived the Chinese factor differently than the US. Moreover, it seems that after 2014, the factor that contributed most to the beginning of the evolution of India's position towards the US was the changing internal context in India, primarily the change in foreign policy assumptions and strategy.

The above premises determined the evolution of Indias position towards the US and its importance in the regional strategy of India. We can distinguish the following periods here: 
a) 2014-2016 - strengthening political relations and creating an institutional framework for cooperation which India intended to serve two purposes: first, to legitimize the Indo-Pacific concept it was promoting and its role in this area; secondly, to increase its economic and technological potential (American investments);

b) 2017-2019 - India’s policy towards the United States was characterized by numerous contradictions, which were the result of two processes: on the one hand, India perceived the US in the context of balancing China's growing power; for India, however, the key was not an open confrontation with Beijing or anti-Chinese rhetoric, but strengthening internal balancing and maintaining the status quo on the Asian continent; on the other hand, the government's economic successes and the rise of nationalist sentiment in India strengthened the traditional faction in the Indian People's Party and some coalition parties that emphasized the need to maintain strategic autonomy. In their opinion, the growing role of India in international relations was possible regardless of cooperation with the US. The uniqueness of India was emphasized. India was perceived as a state-civilization. Hence, although Chinese hegemony in Asia was opposed, maintaining independence and strategic autonomy in relations with the US was also emphasized. Due to these conditions, despite the further institutionalization of political cooperation, the expectations on both sides were divergent, which resulted in disappointment both on the part of New Delhi and the US as the potential of cooperation was not fully exploited (Lalwani \& Byme, 2019, pp. 41-64). At the same time, India feared that the polarization of US relations with China could only serve Washington, not India because its role would be limited in a bipolar regional structure.

c) 2020-2021 - tensions on the border with China and the course of the COVID-19 pandemic in India and its social and economic consequences, and the new US strategy in the Indo-Pacific region have opened a new stage in India's relations with the United States. The role of the US in India's strategy went beyond the existing political, military and economic framework. Washington began to play the role of the main strategic partner in the political dimension and began to be perceived as an ally in non-military security issues. Such a formula, in turn, allows India to treat the US as the main pillar in balancing China, even more so because after 2020, India realized that in the face of internal challenges and the dynamics of China's power growth, maintaining the status quo in the region and opposing the regional order imposed by China can only be ensured by external balancing, i.e., the institutionalization of political, military, economic and other types of cooperation with the US and its allies.

Referring to the first stage, the government of N. Modi considered relations with the US primarily to legitimize its role on the Asian continent. Such a guarantee was to be provided by the new concept of the Indo-Pacific region, in which India would play a much more important role than in the Asia-Pacific region. India did not want to passively support the 
principles of such order but to be a creator of values, norms, and an active participant in the processes shaping the Indo-Pacific region (Panda, 2018, pp. 83-111; Chellaney, 2017). In the statement issued by the Indian Ministry of External Affairs after a 2018 meeting of representatives of the four countries (India, Japan, Australia, and the US), it was emphasized that the cooperation of these countries in the Indo-Pacific region is aimed at "promoting peace, stability, prosperity (...) and order based on the principles and law, which is to contribute to increasing trust between the countries of the region" (India-Australia-JapanU.S. Consultations, 2018). One of the Indian Ministry of External Affairs representatives spoke about India's unique role in building order in the Indo-Pacific region due to its geographical location, economic potential, and democratic values (Address by Foreign Secretary at the Regional Connectivity Conference, 2018).

The BJP government realized that legitimizing India as one of the pillars of the new Indo-Pacific concept could only occur when relations with the US and its main allies became more active. So, in the 2014-2016 period, we could observe the operationalization of multiple agreements. In addition, new agreements were developed or concluded during this period, mainly in military, political, and strategic cooperation and naval forces.

Assumptions about the Indo-Pacific region held by the government of N. Modi were consistent with those of the American administration. It is reflected, inter alia, as early as in the 2015 declaration on U.S. - India Joint Strategic Vision for the Asia-Pacific and Indian Ocean Region (U.S. - India Joint Strategic Vision..., 2015), signed by Prime Minister N. Modi and President Barack Obama. It was the first such bilateral declaration by New Delhi and Washington, which went beyond bilateral issues and concerned security and stability in the Indo-Pacific region.

At the same time, contrary to the previous period, India implemented the provisions contained in its declarations related to strengthening relations with the US. In June 2015, the agreement on military cooperation between India and the US was extended and enhanced. Compared to the previous one from 2005, cooperation was significantly tightened, especially in the maritime dimension and the military industry. In addition, the US-India Knowledge Partnership in Defense was established in 2015. In 2016, the Maritime Security Dialogue was launched in the $2+2$ format (foreign and defense ministers) (Inaugural India-US Maritime Security Dialogue, 2016). A symbol of New Delhi's new approach to relations with Washington was the signing in August 2016, after more than ten years of negotiations, of the Logistics Exchange Memorandum of Understanding (LEMOA), which allows both sides to use the partner's naval bases and infrastructure (Khurana, 2016). The agreement became fully operational in 2018 .

India welcomed the fact that in 2016 the Obama administration recognized India as a Major Defense Partner (MDP) (Mishra,2017, p. 77), which the US Senate also confirmed on December 8, 2016 (SEC 1262, Enhancing Defense and Security...,2018). India strengthened cooperation with the US, especially in information exchange on the movements of Chinese submarines in the Indian Ocean (Singh, 2017). In 2016, after a four-year break, joint 
exercises of the Indian and US special forces were resumed. India took part in RIMPAC - the largest maritime warfare exercises organized by the US in the Pacific and the US Air Force's Exercise Red Flag.

The period 2014-2016 brought progress in the institutional foundations for a new opening in relations between India and the US. However, this did not mean making India's security interests dependent on an alliance with the United States. In the reports of the Ministry of External Affairs adopted at that time, India indicated that Washington is one of the powers, along with China, Russia, France, Great Britain, the EU, Japan, and Germany, with which New Delhi was tightening bilateral relations, which, in turn, was to serve primarily to strengthen economic growth. This objective was noted, among others, in the Annual Report of the Ministry of External Affairs published in 2017:, Through high-level engagement with the US, China, UK, France, Germany, Japan, and Russia, India leveraged all these important relationships to increase the flow of trade, investment, and technologies into the Indian economy. In each bilateral relationship, the government successfully created the contours of mutually beneficial gains, based on a careful evaluation of opportunities and complementarities and an articulation of concerns where needed" (Annual Report 2015-16, 2016).

A new stage in India's relations with the US began in 2017. India increasingly pointed to the US as an important strategic partner in the Indo-Pacific region, as exemplified, by a joint statement after the meeting of N. Modi with D. Trump, in which India and the US were described as „solid, sustainable democracies” ready to cooperate as „responsible stakeholders in the Indo-Pacific region" (Joint Statement (United States and India: Prosperity Through Partnership), 2017). As D. Scott points out, it was an indirect criticism of "undemocratic China as an irresponsible stakeholder, especially in the South China Sea" (Scott, 2018, p.34). At the same time, India started talks on signing two more agreements on naval cooperation, i.e., the Communication and Information Security Memorandum of Agreement (CISMOA) and the Basic Exchange and Cooperation Agreement (BECA). The first was signed at the beginning of September 2018 as the Communications Compatibility and Security Agreement (COMCASA). Subsequent documents adopted by the American administration and the Congress evidenced further institutionalization of cooperation in the field of security, expanded it, and made it more precise (H.R. 2810, National Defense Authorization Act for Fiscal Year 2018, 2018).

However, during the presidency of Donald Trump, India had to face two main challenges:

a) the issue of defining the level of commitment, engagement, and strengthening of political relations between India and the US;

b) the question of India defining its behavior towards China in the context of the increasingly assertive Chinese strategy on the one hand and the growing tension between the US and China on the other.

Referring to the first issue, India did not consider the institutionalization of political relations with the US and its own role in the context of the growing status of the PRC 
in terms of the classic balance of power in the Indo-Pacific region. On the other hand, Washington began to emphasize the importance of India as one of the main balancers of China in the American offshore balancing strategy (Paul, 2019, pp. 221-242). It is evidenced by, for example, both the US National Security Strategy (National Security Strategy of the United States of America, 2017) of November 2017 and the National Defense Strategy of 2018 (National Defense Strategy, 2018). They both called for cooperation for „deterring aggression" and "maintaining stability" to protect the "free and open international order" (National Defense Strategy, 2018). With the aim of operationalzing these assumptions, the so-called Indo-Pacific Strategy Report of June 2019 called for strengthening defense cooperation at a „level commensurate with that of the United States' closest allies and partners" and urged the strengthening of security cooperation, including military interoperability ${ }^{2}$.

Regarding the second issue, rivalry with China also did not mean a zero-sum game and a pursuit of confrontation for India. First, it would negatively affect New Delhi's priority goal, which is to gain regional and global power. Therefore, the issue of key importance was stability and economic development, which is particularly evident in the Indian Ministry of External Affairs reports for 2017-2020. The 2020 report stresses that „The adjustment of foreign policy to domestic priorities to ensure their constant alignment received close attention" (Annual Report 2019-20,2020). Moreover, despite border tensions, Prime Minister N. Modi held two summits with the Chinese leader Xi Jinping in 2018 and 2019. Secondly, India believed that open competition with China and unequivocal support for the anti-Chinese rhetoric adopted by Donald Trump and the bipolar division of the Indo-Pacific region would reduce India's role and possibilities of asserting influence in the region.

Some researchers and analysts even began to point to the differences in the visions of the international order presented by N. Modi and D. Trump. In this context, the differences related, inter alia, to issues such as voting in the UN (e.g., regarding the opinion of the International Court of Justice on the Chagos Archipelago), voting in the Organization for the Prohibition of Chemical Weapons (voting together with China and Russia against the institution's investigatory and attribution powers regarding chemical weapons attacks), and US-India trade disputes (Lalwani \& Byrne 2019, p. 49). It was emphasized that India continued to stress its strategic autonomy and non-alignment tradition. A reference to these assumptions was made in the speech of the Indian Prime Minister in 2018 at the ShangriLa Dialogue in Singapore, where he emphasized: „India’s friendships are not alliances of containment. We choose the side of principles and values, of peace and progress, not one side of a divide or the other" (Prime Minister's Keynote Address at Shangri La Dialogue, 2018). The report of the Ministry of External Affairs of 2019 emphasized that „with strategic autonomy at its core, India continued to step up its engagement with all the major powers of the world, taking independent decisions in the national interest" (Annual Report 2018-

2 https://media.defense.gov/2019/Jul/01/2002152311/-1/-1/1/DEPARTMENT-OF-DEFENSE-INDO-PACIFIC-STRATEGY-REPORT-2019.PDF 
2019,2019 , p. 4). Although they did not stop the institutionalization of relations between India and the US, these conditions had an impact on its quality and the level of commitment on the part of New Delhi. The best demonstration of this was the position of India towards the revitalization of the concept of cooperation within QUAD in 2017. The leaders of the US, India, Australia, and Japan, met during the ASEAN summit in Manila. Although it was agreed that meetings of representatives of the ministries of these countries would be held, India did not agree to establish regular meetings at the level of heads of diplomacy. From 2017 to 2019, four meetings of representatives of ministries were held. In September 2019, the first meeting at the ministerial level was organized.

The differences concerning the level of QUAD institutionalization did not mean diametric differences in the context of the vision of the regional order. It should be emphasized that at the same time, the vision of the regional order presented by N. Modi was similar to the American one. It is manifested by the fact that China was also perceived in it as a challenge and a threat to the regional order. It is evidenced, inter alia, by the adoption in 2015 of the National Maritime Strategy of India, which, similarly to American strategies, emphasizes the importance of the norms of the international law of the sea and the peaceful settlement of disputes, which should constitute the so-called global commons and the basis of order in the Indo-Pacific region (Annual Report 2018-2019, 2019, p. 5). Narendra Modi declined to attend Belt and Road Initiative Summits in 2015, 2016, and 2017.

India also shared with the US the vision of an Indo-Pacific region. The Ministry of External Affairs report emphasized: „India's Vision for the Indo-Pacific focuses on a free, open, inclusive and rules-based Indo-Pacific. India emphasizes respect for sovereignty and territorial integrity of all nations in the region, equality of all nations, peaceful resolution of disputes, avoidance of use or threat of use of force, and adherence to international laws, rules, and regulations. India's objective is a multi-faceted engagement with all countries in the region and those with interests in it, encompassing political, security, economic, and socio-cultural spheres, aimed at Security and Growth for All in the Region (SAGAR)" (Ensuring Secure Seas: Maritime Security Strategy, 2015). It is also confirmed by the fact that in 2019 a special Indo-Pacific Department was established within the Ministry of External Affairs of India.

The United States remained India's main political partner, which was reflected, inter alia, in upgrading these relations in February 2020 during Donald Trump's visit to India to the Comprehensive Global Strategic Partnership level. The US is India's largest trading partner. In 2019, trade increased by 4.3\%, reaching \$ 148.8 billion (Annual Report 2020-21, 2021, p.21).

It seems that in the period 2017-2019, India agreed in principle with the concept of the Indo-Pacific and had a vision of a regional order similar to that of the US, which, according to India, should be based on liberal democratic values and constitute a guarantee of stability in the region. However, the main differences related to how this vision was implemented, i.e., the roadmap and the instruments. One must agree with S. Lalwani and H. Byrne that 
India strongly opposed participation in any form of political-military coalition, while: „US strategy embraces Indo-Pacific alliances that contribute to a ,networked security architecture capable of deterring aggression, and senior US commanders have called on networks like the Quad for ,counterbalancing and deterring coercion or unrestrained national ambitions"' (Lalwani \& Byrne 2019, p. 47). The position of Vinaya Kaur that India should abandon its hedging strategy towards China and tighten strategic cooperation under QUAD was not dominat among decision-makers in New Delhi (Kaura, 2021, pp. 322-347; Kaura, 2019, pp. 78-102).

It was not until 2020 that the tightening of relations between India and the US accelerated, as evidenced by India's commitment to the process of further institutionalization of the QUAD cooperation and the signing on October 27, 2020, during the third meeting of the $2+2$ formula dialogue (heads of diplomacy and defense of India and the US) of the Basic Exchange Cooperation Agreement (BECA). The transformation of India's approach to cooperation with the US and its allies is also evidenced by the joint MALABAR maritime exercises with India, the US, Japan, and Australia. In this context, it should be noted that previously, despite the suggestions from the American side, India did not agree, fearing both the reactions of China and internal criticism, to the implementation of this concept. At the same time, in 2020, for the first time, in the annual reports published by the Ministry of External Affairs of India, a chapter dedicated to the Indo-Pacific appeared.

The change of India's stance in 2020 was caused predominantly by the two factors:

a) external conditions in the region, and above all, China's more assertive strategy, which was manifested, for example, in the context of Taiwan or the tensions along the Sino-Indian border. Skirmishes in June 2020 between Indian and PLA troops in the Galwan Valley in Ladakh were the first in more than forty-five years of clashes between Indian and Chinese forces in which soldiers were killed. Moreover, the behavior of China in the context of the COVID-19 pandemic and the geo-economic implications of the pandemic in the region and for the world economy were pointed out;

b) a new approach to the Indo-Pacific region and, above all, implementation of the strategy in this area by the administration of US President Joe Biden.

Referring to the first point, India's perception of the geopolitical situation on the continent was the key factor that affected opting again in favor of cooperation with the US and its intensification. The words from the report of the Ministry of External Affairs Report published in 2020 confirm the above thesis: „External challenges during this period included substantial changes in geopolitical equations including major shifts in great power policy on regional issues and countries, potentially disruptive technologies and global technology regimes and the response to major international issues such as migration, climate change and global economic and development governance" (Annual Report 2019-20, 2020, p. 16). Harsh V. Pant and Premesha Saha emphasized that in the new geopolitical conditions ,the choice to work closely with like-minded countries and develop a stronger stance against 
China's, not so peaceful rise' is viewed as a priority by New Delhi”' (Pant \& Saha, 2020, p. 180). India's Minister of External Affairs S. Jaishankar emphasized that confrontation in Ladakh: "profoundly disturbed the relationship" and had a negative impact on the perception of China by public and political opinion in India (Jaishankar, 2021). Some Indian strategists and analysts even pointed out that China should be clearly defined as the enemy after the post-Galvan period. S. Kapila wrote: „China is an implacable enemy of India, and pretending otherwise is strategic myopia" (Kapila, 2020). Although the statements of Prime Minister N. Modi or the Indian Minister of External Affairs and the documents adopted by the ministries did not define China as an enemy or a threat, there is no doubt that, as Tanvi Madan points out, „Beijing's assertiveness has caused to re-evaluate India's autonomy-alignment balance” (Madan, 2020, p. 53). Compared to previous border disputes and tensions with China, India has not tried to avoid decisions that Beijing may view negatively and escalate tensions. It is evidenced by, for example, participation in the ministerial meeting of the QUAD group, joint maritime exercises with the participation of American an aircraft carrier, or the refueling of American P-8A reconnaissance aircraft at Port Blair (Andaman and Nicobar Islands) (Madan, 2020, p. 54).

At the same time, referring to the second point, whether the election of the new US President, Joe Biden and his administration's new approach to the Indo-Pacific region were the factor that catalyzed India's closer cooperation with Washington, it should be noted that anti-Chinese rhetoric and bilateralism were replaced by a strategy based on multidimensionality instead of the logic of competition between the two blocs. That is why India welcomed the new concept of the QUAD Plus, which goes beyond traditional security mechanisms. New Delhi was also comforted by the Biden administration's approach to the Indo-Pacific, which is set within a broader context of liberal democracy versus authoritarianism. The reconceptualized QUAD Plus aligns with Indian interests, evidenced by the new US approach towards the Indo-Pacific. Championing a rules-based order not through confrontation but by emphasizing soft power instruments, values and norms is a better scenario for closer US-India cooperation in the Indo-Pacific region. The new US approach to implementing the strategy in the Indo-Pacific has created an opportunity for India to cooperate more closely with Washington, mainly in combating non-military threats, focusing on non-military security issues, and infrastructure cooperation.

The main distinguishing feature of this period was putting stress by India on close cooperation with the US in guaranteeing global common goods not only in the Indo-Pacific region but also beyond it. It is evidenced by, inter alia, the US-India Joint Leaders' Statement: A Partnership for Global Goods from September 24, 2021 (U.S.-India Joint Leaders'Statement: A Partnership for Global Good, 2021). In this context, the words of Prime Minister N. Modi during his speech at the QUAD summit in Washington on September 24, 2021, are significant: „QUAD has decided to move forward with positive thinking and a positive approach. Whether it is a supply chain, global security, climate action or COVID-19, or cooperation in technology, I will be very happy to discuss these issues with my colleagues. 
Our QUAD will work in a way in the role of ,force for global good'. I am confident that our cooperation in QUAD will ensure peace and prosperity in Indo-Pacific and the world" (Prime Minister's opening remarks at QUAD, 2021).

The global partnership between India and the US in the sphere of declarations and conceptualizations was visible, inter alia, in joint statements by the leaders of India, the US, Australia, and Japan after two QUAD summits, a virtual summit in March 2021 and a summit in September 2021 in New York (Joint Statement from Quad Leaders, 2021). The role of the partnership with the US is to strengthen the position of India as one of the active co-leaders of not only the regional but also the global order. In the Ministry of External Affairs report from 2021, India describes itself for the first time as a „responsible international citizen" (Annual Report 2020-21, 2021, p. 8). In this regard, India wants to cooperate with the US and its allies, which Prime Minister N. Modi clearly stated at Global Summit on Supply Chain Resilience in October 2021 (Prime Minister's address at Global Summit on Supply Chain Resilience, 2018).

\section{Conclusions: Relevance of Neoclassical Realism and Institutional Balancing in Researching the Role of the US in India's Strategy in the Indo-Pacific Region}

The application of insights from neoclassical realism and institutional balancing help answer the main research question and confirm the hypothesis that the role of the United States has assumed increasing importance in India's Indo-Pacific strategy over the past seven years. The rise of China, the changing external environment, and India's great power aspirations, including strengthening its own economic capacities, have combined to drive India's closer relations with the US. But domestic factors, such as strategic culture, history have meant that heightened perceptions of external threats have not led to an alliance relationship between the US and India.

If only applying a realist perspective, it would suggest that India should seek a political and military alliance with the US. It has not occurred because of domestic factors, which include India's perception itself as a unique actor valuing its distinct „strategic autonomy”. The pursuit of strategic autonomy is rooted in the principles of non-involvement and is related to the cultural and civilization heritage. One of the features of the Indian worldview is its Indo-centricity. The international order and its evolution are analyzed in the context of Indian culture, civilization, and history. Indians perceive their state in categories of statecivilization. Regardless of political differences, New Delhi is concerned with recognizing their role by other powers. At the same time, there is a consensus among India's strategic elite that „eventually the world will accept the truth about our role in the world” (Pant, 1989). Moreover, state-centricity, idealization, and sacralization of the territory continue to play an important role in the Indian vision of the world, and postcolonial experiences are present in the Indian strategic discourse. Although their influence is no longer as significant as during 
the Cold War or in the 1990s, S. Ganguly's thesis, that during the rule of N. Modi, India abandoned its attachment to the principle of non-alignment and the principle of strategic autonomy, does not seem entirely justified (Ganguly, 2017, p. 132). First, India is not making sudden changes. As a rule, the Indians are opponents of revolution. They prefer evolution in both economics and politics. In this context, some researchers define India as a so-called reformist state, which in its foreign policy is guided by pragmatism, an evolutionary approach to the regional order and stability (Gupta, 2006, p. 78).,Persistence, survival, immutability are also important, as are progress and development. India is therefore based on the rational assumption that an elephant cannot be a tiger (...) However, it has enormous strength, the impetus of which will overcome all obstacles. In the Indian vision of development, the idea of small steps supported by reason prevails" (Tokarski \& Bhutani, 2007, p. 58). Secondly, referring, after Rohan Mukherjee, to the model of Isaiah Berlin, it should be pointed out that most countries perceive strategic autonomy in terms of negative liberty, i.e., freedom from external interference. On the other hand, India still considers it in terms of positive liberty, i.e., freedom to pursue certain goals (Mukherjee, 2020, p.429; Berlin, 1969). The specificity of India lies in the fact that it presents the issues of international relations through the prism of its aspirations, identity, and strategic culture. India is reluctant to enter into formal alliances with stronger states, fearing that it will find itself in a secondary or subordinate position (Mukherjee, 2020, p. 429). Thus, the assumptions of neoclassical realism, drawing attention to the need to analyze decisions in foreign policy through the prism of internal factors, perceptions, and strategic culture, serve to explain why India will protect the preservation of autonomy, also in relations with the US. It intends to play the role of an equal partner and not a subordinate state. One Indian analyst said unequivocally: „New Delhi will not replace Islamabad as Washington's willing and subservient ally" (Sarkar, 2015).

On the other hand, India's approach to the US cannot be explained solely in terms of historical identity, which would not account for the substantial development of relations in the last years. That stands as confirmation again of the relevance of neoclassical assumptions, which take into account rational criteria and cost-benefit calculations, while treating external factors like China's rise as independent variables. Despite reservations, India started to develop closer relations with the US after 2014 because it was a function of its plan to increase its own role in the Indo-Pacific.

The change in India's stance towards the US, especially after 2014, consisted in a departure from India's cautious approach to such cooperation, which was manifested in emphasizing that Washington is one, but not the only one pillar of India's security in favor of recognition, especially after 2020, of cooperation with the US and its allies in the IndoPacific as a cornerstone of India's regional strategy in the region. Engagement has become the keyword in India's relationship with the US. Relations with the US and other members of the Quadrilateral Security Dialogue (QUAD) constitute, especially since 2021, one of the pillars of democratic, liberal order in the Indo-Pacific region and the world as an alternative to the order proposed by China. 
This alternative does not mean confrontation for India, so the neorealist assumption is irrelevant. India is fully aware that polarization and bipolarism in the Indo-Pacific will limit its role in the region. China is a competitor, but at the same time, China is one of India's main trade partners. India is not in favor of confrontation and an open containment policy against China. Considering the assumptions of neoclassical realism (the significance of domestic interests, factors like economic development, and rational, egoistic cost-benefit calculations), it is not in the interest of India.

However, at the same time, taking into account the core causal mechanism in the model of institutional balancing, which is the rationality criterion in the form of cost-benefit calculations (and expectations), India realizes that maintaining the current liberal international and regional order is crucial to India's regional and Great-Power aspirations and also its security and prosperity.

Closer cooperation with the US, especially after 2020, is explained by India putting more stress on internal and external balancing, i.e., the issue of concluding agreements, creating institutions, and forms of consultations with other states. India is aware that dealing with the rise of China and the new geopolitical situation in the Indo-Pacific and the social-economic implications of the pandemic in India by only strengthening its own economic potential is not adequate any longer. On the other hand, taking into account the complexity and interdependence that characterize India-China-US relations along with the important cultural heritage of India and its domestic circumstances, India will develop political relations with the US in order to counter pressures or threats from China and also in order to fulfill its own aspirations by initiating and using multilateral institutions other than traditional military alliances. Moreover, it will develop cooperation with the US and its partners in non-military spheres.

During the post-Galvan and post-pandemic periods, India's Indo-Pacific strategy is closely linked to the global dimension of its politics. India began to consider its strategy in the region in the democratic, liberal regional order and, more broadly, the global order. Countries such as the USA want to be the guarantor of global common goods. The narrative of Joe Biden's administration de facto serves the interests of India, as it allows it to escape the „Chinese trap", that is, to view its activity in the region mainly in the context of relations with China or, more broadly, the US-China rivalry. These activities are in line with the assumptions of inclusive institutional balancing, which emphasizes that „states practice norm/rule-building to constrain other states' behavior” (He, 2008, p. 493).

That is why India has started to articulate a joint vision of a democratic and liberal regional and global order with the US and its allies. Indeed, India does not strive with the USA and its allies to „consolidate their political and economic unity to resist pressure” (as assumed by exclusive balancing) (He, 2008, p. 493) from China. India wants and prefers norms/rule building to create with the US - using soft power instruments - an alternative to China's vision. It is reflected in the joint vision adopted by Modi and Obama in 2015 and two years later by Trump and Modi. In 2021 it was also reflected in Modi and Biden's 
statements. This evidence indicates that India treats the Indo-Pacific and since 2020 the QUAD as political concepts, and it opposes the vision not only of the regional but also global order presented by China (Paik \& Park, 2021, pp. 36-52; Rai, 2018, pp. 138-148; Panda, (2018, pp. 83-111). India is therefore trying to prevent a change in the balance of power in favor of Beijing both in Asia and globally, which would enable China to impose its vision of the world. Hence, India favors strengthening closer cooperation with the US, aligned with Washington. But it will be based on the formula of coalitions with an issue or „interest-based groupings that include some allies but also other states willing to align on areas of convergence" (Madan, 2020, p. 56).

\section{References:}

Address by Foreign Secretary at the Regional Connectivity Conference: South Asia in the Indo-Pacific Context. (2018, November 1). Speeches and Statements, Ministry of External Affairs, Government of India. https://www.mea.gov.in/Speeches-Statements.htm?dtt/30556/Address_by_Foreign_Secretary_at_the_Regional_Connectivity_Conference_South_Asia_in_the_IndoPacific_Context

Annual Report 2015-16, Ministry of External Affairs. (2016). http://www.mea.gov.in/Uploads/PublicationDocs/26525_26525_External_Affairs_English_AR_2015-16_Final_compressed.pdf

Annual Report 2018-2019, Ministry of External Affairs. (2019). http://www.mea.gov.in/Uploads/ PublicationDocs/31719_MEA_AR18_19.pdf

Annual Report 2019-20, Ministry of External Affairs. (2020). http://www.mea.gov.in/Uploads/PublicationDocs/32489_AR_Spread_2020_new.pdf

Annual Report 2020-21, Ministry of External Affairs. (2021). http://www.mea.gov.in/Uploads/PublicationDocs/33569_MEA_annual_Report.pdf

Asia Reassurance Initiative Act of 2018 (Briefing Paper). (2018, April 24). https://gardner.senate.gov./ imo/media/doc/ARIA\%20one-pager.pdf

Ball, D. (1993). Strategic Culture in the Asia-Pacific Region. Security Studies, 1, 44-74.

Baru, S. (2014). The Accidental Prime Minister: The Making and Unmaking of Manmohan Singh. New Delhi.

Berlin, I. (1969). Four Essays on Liberty. Oxford.

Brewster, D. (2014). India's Ocean: The Story of India's Bid for Regional Leadership. Routledge.

Chacko, P. (2014). The Rise of the Indo-Pacific: Understanding Ideational Change and Continuity in India's Foreign Policy. Australian Journal of International Affairs, 4, 433-452.

Chacko, P. (Ed.) (2016). New Regional Geopolitics in the Indo-Pacific: Drivers, Dynamics and Consequences. London and New York.

Chandra, S., \& Ghoshal, B. (Eds.) (2018). The Indo-Pacific Axis: Peace and Prosperity or Conflict? London and New York.

Chellaney, B. (2017, November 17). Democratic Forces Must Join Hands to Protect Indo-Pacific from China's Hegemony. The Hindustan Times.

Clinton, H. (2011, July 20). Secretary of State Hillary Rodham Clinton on India and the United States: A Vision for the $21^{\text {st }}$ Century. http://iipdigital.usembassy.gov/st/english/texttrans/2011/07/201107 20165044su0.7134014.html\#ixzz1UxWVNLPL 
Clinton, H. (2011, October 11). America’s Pacific Century. Foreign Policy. http://www.state.gov./secretary/ $\mathrm{rm} / 2011 / 10 / 175215 . h t m$

Czaputowicz, J. (2014). Mapa współczesnego realizmu: realizm klasyczny, neorealizm, realizm neoklasyczny (Map of contemporary realism: classical realism, neorealism, neoclassical realism). In E. Haliżak, \& J. Czaputowicz (Eds.), Teoria realizmu w nauce o stosunkach międzynarodowych. Założenie $i$ zastosowania badawcze (The theory of Realism in the International Relations Science. Assumption and Research Applications) (pp. 25-42). Warszawa.

Ensuring Secure Seas: Maritime Security Strategy. (2015). Indian Navy. https://www.indiannavy.nic.in/ sites/default/files/Indian_Maritime_Security_Strategy_Document_25Jan16.pdf

Ganguly, S. (2017). Has Modi truly changed India's Foreign Policy? The Washington Quarterly, 2, 132.

Garge, R. (2017). Maritime Outreach as Part of India's ,Act East' Policy. Australian Journal of Maritime \& Ocean Affairs, 3, 150-167.

Gopal, D., \& Ahlawat (Eds.) (2016). Indo-Pacific: Emerging Powers, Evolving Regions and Challenges to Global Governance. New Delhi.

Gupta, A. (2006). US-India-China: Assessing Tripolarity. China Report, 1, 78.

H.R. 2810, National Defense Authorization Act for Fiscal Year 2018, 115 ${ }^{\text {th }}$ Congress (2017-2018). www.congress.gov/bill/115 ${ }^{\text {th }}$-congress/house-bill/2810/text

Haliżak, E. (1999). Stosunki Międzynarodowe w regionie Azji i Pacyfiku (International Relations in the Asia-Pacific region). Warszawa.

Hall, I. (2016). Multialignment and Indian Foreign Policy under Narendra Modi. The Round Table. The Commonwealth Journal of International Affairs, 3, 271-286.

He, K. (2008). Institutional Balancing and International Balancing Theory: Economic Interdependence and Balance of Power Strategies in Southeast Asia. European Journal of International Relations, 3, 489-518.

https://mea.gov.in/bilateral-documents.htm?dtl/34318/joint+statement+from+quad+leaders

https://mea.gov.in/Speeches-Statements.htm?dtl/34317/prime+ministers+opening+remarks+at+quad

https://media.defense.gov/2019/Jul/01/2002152311/-1/-1/1/DEPARTMENT-OF-DEFENSE-INDOPACIFIC-STRATEGY-REPORT-2019.PDF

Inaugural India-US Maritime Security Dialogue. (2016, May 18). Ministry of External Affairs, Government of India.http://www.mea.gov.in/press-releases.htm?dtl/26829/Inaugural+IndiaUS+Maritine+ Security+Dialogue

India as „Global Swing State”: A New Framework for U.S. Engagement with India. (2013). The National Bureau of Asian Research. https://www.nbr.org/publication/india-as-a-global-swing-state-a-newframework-for-u-s-engagement-with-india

India-Australia-Japan-U.S. Consultations. (2018, November 15). Press Releases. Ministry of External Affairs, Government of India. https://www.mea.gov.in/press-releases.htm?dtl/30593/IndiaAustraliaJapanUS_Consultations

Jackson, P.T. (2011). The Conduct of Inquiry in International Relations: Philosophy of Science and Its Implications for the Study of World Politics. London.

Jaishankar, S. (2021, January 28). Keynote Address by External Affairs Minister. $13^{\text {th }}$ All India Conference of Chinese Studies. Ministry of External Affairs. https://mea.gov.in/Speeches-Statements. htm?dtl/33419

Joint Statement (United States and India: Prosperity Through Partnership). (2017, June 27). https:// www.whitehouse.gov/briefings.statements/united-states-india-prosperity-partnership

Joint Statement from Quad Leaders (2021, September 24). Quad Leaders' Joint Statement: „The Spirit 
of the Quad". https://mea.gov.in/bilateral-documents.htm?dtl/33620/quad+leaders+joint+stateme $\mathrm{nt}+$ the + spirit + of + the + quad

Kapila, S. (2020). China is an implacable enemy of India - pretending otherwise is strategic myopia. Paper. South Asia Analysis Group.

Kaura, V. (2019). Incorporating Indo-Pacific and the Quadrilateral into India's strategic outlook. Maritime Affairs: Journal of the National Maritime Foundation of India, 2, 78-102.

Kaura, V. (2021). India's Quadrilateral conundrum. India Review, 3, 322-347.

Khurana, G.S. (2016, September 8). Indo-US Logistics Agreement LEMOA: An Assessment. National Maritime Foundation (NMF). http://maritimeindia.org/View\%20Profile/636089093519640938.pdf Kozub-Karku, M.(2020). Realizm neoklasyczny w perspektywie teorii stosunków międzynarodowych i polityki zagranicznej (Neoclassical Realism in International Relations and Foreign Policy Theories Perspectives). Kraków.

Lalwani, S., \& Byrne, H. (2019). Great Expectations: Asking Too Much of the US-India Strategic Partnership. The Washington Quarterly, 3, 41-64.

Madan, T. (2020). Not Your Mother's Cold War: India’s Options in US-China Competition. The Washington Quarterly, 4, 53.

Marszałek-Kawa, J., \& Bodio, T. (Eds.) (2016). Polityka bezpieczeństwa w regionie Azji i Pacyfiku. Wydawnictwo Adam Marszałek.

Marszałek-Kawa, J., \& Kinelski, G. (Eds.) (2019). Współczesne bezpieczeństwo regionu Azji i Pacyfiku. Wybrane problemy. Wydawnictwo Adam Marszałek.

Mishra, V. (2017). Indo-US Security Cooperation: Implications for the Indian Ocean. Maritime Affairs. Journal of the National Maritime Foundation of India, 1, 77.

Mukherjee, R. (2020). Chaos as opportunity: the United States and world order in India's Grand Strategy. Contemporary Politics, 4, 429.

National Defense Strategy, 2018. (2018). Department of Defense. Washington.

National Security Strategy of the United States of America. (2017, December). https://www.whitehouse. gov/wp-content/uploads/2017/12/NSS-Final-12-18-2017-0905.pdf

New Defense Bill Underscores U.S. Shift to Indo-Pacific Strategy. (2018, May 8). Xinhua.

Oertel, J., Small, A., \& Studdart, A. (2018). The Liberal Order in the Indo-Pacific. Asia Programme, The German Marshall Fund, 13.

Paik, W., \& Park, J.J. (2021). The QUAD’s Search for Non-Military Roles and China's Strategic Response: Minilateralism, Infrastructure Investment, and Regional Balancing. Journal of Contemporary China, $127,36-52$.

Pan, Ch. (2014). The ,Indo-Pacific' and Geopolitical Anxieties about China's Rise in the Asian Regional Order. Australian Journal of International Affairs, 4, 453-469.

Panda, J.P. (2018). India's Call on China in the QUAD: A Strategic Arch Between Liberal and Alternative Structures. Rising Powers Quarterly, 2, 83-111.

Pant H.V., \& Saha, P. (2020). India, China, and the Indo-Pacific: New Delhi's Recalibration Is Underway. The Washington Quarterly, 4, 180.

Pant, H.V. (2019). The India-US-China triangle from New Delhi: overcoming the „hesitations of the history. India Review, 4, 394.

Pant, K.C. (1989, July 1). Philosophy of Indian Defense. Address to the Massachusetts Institute of Technology.

Pant, R.H.V., \& Rej, A. (2018). Is India ready for the Indo-Pacific? Washington Quarterly, 2, 47-61. 
Pattanaik, S.S. (2016). Indian Ocean in the Emerging Geo-strategic Context: Examining India's Relations with its Maritime South Asian Neighbors. Journal of the Indian Ocean Region, 2, 126-142.

Paul, J. (2019). US and India: Emerging offshore balancing in Asia. India Review, 3, 221-242.

Paul, T.V., \& Underwood, E. (2019). Theorizing India-US-China strategic triangle. India Review, 4, 348-367. Powell, N. (2012, February 7). Statement (to Senate Foreign Affairs Committee) of 7 February 2012.

Prime Minister's address at Global Summit on Supply Chain Resilience, https://mea.gov.in/Speeches-

Statements.htm?dtl/34458/prime+ministers+address+at+global+summit+on+supply+chain+resili ence

Prime Minister's Keynote Address at Shangri La Dialogue. (2018). Ministry of External Affairs. https:// www.mea.gov.in/Speeches-Statements.htm?dtl/29943/Prime+Ministers+Keynote+Address+at+Sha ngri+La+Dialogue+June $+01+2018$

Prime Minister's opening remarks at QUAD, 24 September 2021, Ministry of External Affairs. (2021). Quadrennial Defense Review 2014. (2014). Department of Defense. United States of America, Washington. Rai,A. (2018). Quadrilateral Security Dialogue 2 (QUAD 2.0) - a credible strategic construct or mere, foam in the ocean'? Maritime Affairs: Journal of the National Maritime Foundation of India, 2, 138-148.

Raja Mohan, C. (2006, July/August). India and Balance of Power. Foreign Affairs. https://www.foreignaffairs. com/articles/asia/2006-07-01/india-and-balance-power

Rose, G. (1998). Neoclassical Realism and Theories of Foreign Policy. World Politics, 1, 144-172.

Roy-Chaudhury, R., \& Sullivan de Estrada, K. (2018). India, the Indo-Pacific and the Quad. Survival, 3, 181-194.

Sarkar, J. (2015, March 6). Strategic Passing: Why India will not be Pakistan 2.0 in U.S. Asia Policy. Foreign Policy.

Scott, D. (2018). The Indo-Pacific in US Strategy: Responding to Power Shifts. Rising Powers Quarterly, 2,34 .

Scott, D. (2021). India's China's Challenge: Foreign Policy Dilemmas Post-Galwan and Post-Covid. The Journal of Indian and Asian Studies, 2. DOI: 10.1142/S2717541321400039

SEC 1262, Enhancing Defense and Security Cooperation with India, H.R. 4909, National Defense Authorization Act for Fiscal Year 2017, $114^{\text {th }}$ Congress (2015-2016). www.congress.gov/bill/114 ${ }^{\text {th }}$ congress/house-bill/4909/text

Singh, S. (2014). From a Sub-Continental Power to an Asia-Pacific Player: India’s Changing Identity. India Review, 3, 187-211.

Singh, S. (2017, January 19). US, Indian Navies Sharing Information on Chinese Subs, Says Pacific Command Chief. Indian Express.

Sustaining U.S. Global Leadership: Priorities for $21^{\text {st }}$ Century Defense. (2012). Department of Defense. United States of America, Washington.

Tandon, A. (2016). India's Foreign Policy Priorities and the Emergence of a Modi Doctrine. Strategic Analysis, 5, 349-356.

Tokarski, S., \& Bhutani, S. (2007). Nowoczesne Indie. Wyzwania rozwoju (Modern India. Development Challenges). Warszawa.

U.S. - India Joint Strategic Vision for the Asia-Pacific and Indian Ocean Region. (2015, January 25). Ministry of External Affairs (MEA), Government of India. http://mea.gov.in/bilateral-documents. htm?dtl/24728/USIndia_Joint_Strategic_Vision_for_the_AsiaPacific_and_Indian_Ocean_Region

U.S.-India Joint Leaders' Statement: A Partnership for Global Good. (2021, September 24). https:// mea.gov.in/bilateral-documents.htm?dtl/34320/usindia+joint+leaders+statement++a+partnership + for+global+good + september $+24+2021$ 
White T. J. (2019). Navigating two Asias: how Washington deals with the Indo-Pacific's rising powers. India Review, 4, 407-436.

Willard, R. (2012, January 27). Asia-Pacific U.S. Military Overview.

Wohlforth, W. (1994). Realism and the End of the Cold War. International Security, 3, 91-129.

Zajączkowski, J. (2011). Czynnik amerykański w indyjskiej strategii międzynarodowej u progu XXI wieku - w kierunku strategicznego partnerstwa? In J. Nakonieczna, \& J. Zajączkowski (Eds.), Azja Wschodnia i Azja Południowa w stosunkach międzynarodowych (pp. 487-508). Warszawa.

Zajączkowski, J. (2015). Strategie morskie Indii, Chin i USA w regionie Oceanu Indyjskiego (Maritime Strategies of India, China and the USA in the Indian Ocean Region). Stosunki MiędzynarodoweInternational Relations, 2, 37-70. 